\section{Cultural Apropriation: a roundtable}

Quote: ASEGA, Salome; BHABHA, Homi K.; BORDOWITZ, Gregg; KEE, Joan; KUO, Michele; KURIAN, Ajay; SATTERWHITE, Jacolby. Apropriação cultural: uma mesa redonda. Porto Arte: Revista de Artes Visuais. Porto Alegre: PPGAVUFRGS, v. 22, n. 37, p1-14, jul.-dez. 2017. e-ISSN 2179-8001. DOI: http://dx.doi. org/10.22456/2179-8001.80139

Artforum as original publishe (c) Artforum, Summer 2017, "Cultural Appropriation: A Roundtable," by Salome Asega, Homi K. Bhabha, Gregg Bordowitz, Joan Kee, Michelle Kuo, Ajay Kurian, and Jacolby Satterwhite. <https://www.artforum.com/ inprint/issue $=201706$ Eid $=68677>$

CULTURE IS ITSELF an act of citation-of reference, response, and transformation. From Mayan iconography to Warhol, the Pictures generation to Nanook, orientalism to punk, art has copied, taken, simulated, re-created, and appropriated all manner of images, styles, texts, and experiences. When is such movement a form of resistance, and when is it a form of violence? When is speech free, and when does it harm? Such debates have long raged in the visual arts as in documentary film, sociology, anthropology, and history, but they have taken on a new cast in this time of social media, microaggressions, branding, and a vastly exploded terrain for the circulation of ideas and images. In the pages that follow, artists Salome Asega, Ajay Kurian, and Jacolby Satterwhite; scholars Homi K. Bhabha and Joan Kee; Artforum editor Michelle Kuo; and writer, artist, and activist Gregg Bordowitz examine these urgent and omnipresent politics of representation, appropriation, and power.

\section{HOMI BHABHA:}

Let's start with a proposal: I prefer translation to appropriation. The process of translation is a process of interpretation, of relocation-of producing, as Walter Benjamin says, "in another place, something new, which bares the trace of"-I won't call it "the original," but I will call it the anterior, the anterior without priority. Translation assumes that there is a prior state-whether it's a text, or a prior historical moment, or a prior identity, there is something anterior to that which becomes translated. Unlike appropriation, translation is a relationship that does not
Michele Kuo Jacolby Satterwhite

Ajay Kurian immediately give a default value to some kind of original; the anterior is not seen as the "appropriate" or "original" text.

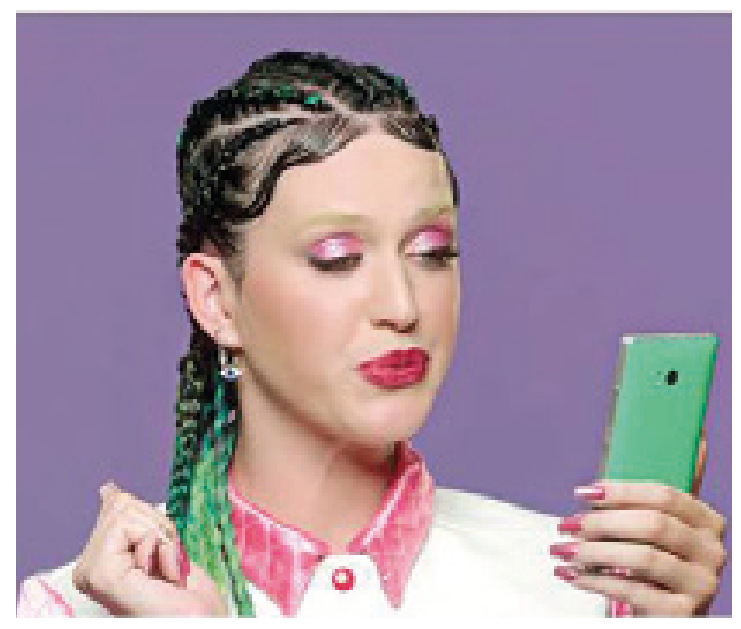

Figure 1. Still from Katy Perry's 2014 video This Is How We Do, directed by Joel Kefali.

By avoiding such default assumptions, you can actually begin to understand whether or not you think the appropriation in any given instance is just or unjust, or inaccurate, or insulting, provocative or problematic, or reductive.

\section{AJAY KURIAN:}

On a conceptual level, I agree with replacing appropriation with translation. But when we change the phrase cultural appropriation to cultural translation, how does the significance shift? What do we lose along the way?

\section{JACOLBY SATTERWHITE:}

Cultural appropriation is having this trending hashtag moment, and yet it's a term that is becoming obsolete.

Kids don't learn local vernaculars anymore. That's a shift that dates at least a couple of decades back. When I grew up in Columbia, South Carolina, I learned how to do certain dance moves at the corner store down the block from my house. Black people from all over the country somehow picked up on the same affects. But the situation now is more extreme. 
Now, kids born after 1998 don't recognize regional distinctions at all-they recognize tutorials, imitating dance moves, vlogs, podcasts, which might come from anywhere. When I was fourteen, I would go home and watch my Madonna, Janet, and Sade DVDs and study them every day. I'm sure the kids are doing the same thing. It's like a dreamscape, where you do things that are unfamiliar and not connected to your own experience at all.

\section{HOMI BHABHA:}

If the same dance moves are learned through YouTube in Botswana and then Bombay and then somewhere else, that's a kind of infectious cultural representation. It's interesting that nobody makes the claim of appropriation until somebody feels that something inappropriate is happening. And it's only then, when someone has made the charge of appropriation, that a certain discussion begins.

\section{SALOME ASEGA:}

To me, appropriation is a word that still has value and still seems useful. I'm thinking specifically about a video game I worked on with Ali Rosa-Salas, Chrybaby Cozie, and other "lite feet" dancers, who are sort of the keepers of the Harlem Shake. We made the game right after Baauer's Harlem Shake dance craze went viral, and after it was released, you would have to go pages and pages into YouTube to find the original Harlem Shake.

And that word was so useful for us in explaining our motivations, because we were describing a sort of erasure that happened because of a particular power structure. That's the only word. Translation and citation don't explain the power at play between the groups.

\section{HOMI BHABHA:}

You cannot use appropriation for all forms of cultural exchange or all forms of cultural intersection, though. It's about a specific thing, I think.

\section{MICHELLE KUO:}

And translation would seem to account for power relations-it just doesn't characterize them in advance, like appropriation. But when is appropriation appropriate to use?

\section{JACOLBY SATTERWHITE:}

In pop culture, appropriation never becomes controversial until the performer who's doing it becomes popular or successful. I've been watching Iggy Azalea's career since 2007, and at first her fan base was very diverse, and no one had a problem with her when she was undergroundin fact, it was edgy to like her. And then once she had a number-one hit ... I'm a gossip-column person, so I saw the exact moment when her growing power brought about this vilification.

And power, or the lack of it, might also help explain why the term appropriation is sometimes abused now. I think a lot of people are stressed out in these hard times, and a lot of people want something to own.

\section{JOAN KEE:}

I think one of the optics of critique is really the frame of ownership. The word appropriationbasically comes from ecclesiastical law, where it denoted the idea that one body can annex something exclusively. We almost seem to be returning to that conception, which is one of the reasons I think appropriation has run its course, exhausted its utility, as something we talk about in terms of borrowing or taking or translation. It seems there's more and more contention around appropriation as a juridical matter, where deciding who uses what is really up to the law. And competing claims start to divide people who should in theory come together to form some kind of commons, rather than endorsing these very procedural ways of thinking, which tend to create divisions: "This is yours and that's mine."

\section{MICHELLE KUO:}

Which replicates precisely the kind of ownership and authorship that are part of the power structure in the first place.

\section{HOMI BHABHA:}

Unlike citation or quotation, appropriation assumes a proprietorial sense: Who owns what? In what sense do I 
own my history, or you own your art? Related to that notion of ownership is the sense of in propria persona: who can speak for it if it is owned. This makes the term problematic in the following way: To put it very generally, in the history of oppression-of those who are oppressed by racial discrimination, gender issues, colonialism, violencethe oppressed are the subjects of a certain history, which becomes in some way their own. That is their experience. But that experience has also been created by the oppressor-so there is a duality, at least.

You would not want to say that the history of colonialism, or of slavery, is only the history of natives or of slaves, because their tragic history has itself been the consequence of a relationship - a relationship that is violent, hegemonic, ethically unacceptable, and politically oppressive. All forms of oppression, like all forms of resistance, or all forms of power authorization, are relational. This was how Frantz Fanon thought about it: If there is to be change, the change is not only going to come through the justified and courageous resistance of those who are oppressed. It is also going to have to displace the positions of hegemony and oppression.

That is why I think that you cannot simply own your own history of being oppressed, or of suffering. Of course that experience is specific. Of course it creates its own communal language and experience. It creates its own ability to construct a history. But it has to be seen in terms of relationality, of a history of dynamic interactions.



Figure 2. Dara Birnbaum, Technology/Transformation: Wonder Woman, 1978-79, video, color, sound, 5 minutes 50 minutes.

\section{GREGG BORDOWITZ:}

I'm fifty-two, and I was in art school in New York when appropriation came into use as a strategy in the early 1980s. Appropriation was understood as a tactic of the counterculturein art, but also in a larger counterculture encompassing left-wing liberation struggles over race, gender, sexuality. . . . So many other connotations have attached to the term since I formed my early, perhaps limited, understanding of it.

Ultimately, the issue of appropriation for us, at that time, had to do with taking material that we didn't have legal or technological access to. The touchstone examples were Sherrie Levine, Barbara Kruger, Jenny Holzer, and members of the Pictures generation; but l'm thinking particularly of Dara Birnbaum and the video Technology/Transformation: Wonder Woman [1978-79], which used a copy of footage from the popular network TV show.

So appropriation actually meant theft, and it was a way of acknowledging that property is theft, and that those who don't have access have to appropriate the means of production and the materials of culture as a critical act. There was a lot of discussion at that time about the economic aspects, about white culture's theft of rock and roll, for example; denial of publishing rights; economic injustices that rendered certain authors invisible.

And there are still people being ripped off monetarily, people from cultures that don't have access to means of production.

\section{JACOLBY SATTERWHITE:}

So maybe appropriation could be seen as an intellectual device, but when it bleeds into mass culture, it becomes something else.

\section{SALOME ASEGA:}

But the device you're describing here is akin to what, say, Yellow Jackets Collective or BUFU are doing-

\section{JACOLBY SATTERWHITE:}

You mean FUBU?

\section{SALOME ASEGA:}

No, it's a collective and multimedia project-By Us For Us. Legally they can't use FUBU [the brand] because it's trademarked, so: BUFU—By Us For Us. These collectives of artists and political educators use scamming instead of appropriation. 
And I'm all for scamming, which is about realizing that, in order to survive, you have to appropriate the signs and the language of people in power in order to attain institutional resources. If we're being particular about language, I like scamming.

\section{JACOLBY SATTERWHITE:}

I like it too. Can this article be called "Scamming"?

\section{HOMI BHABHA:}

This notion of scamming suggests that there are better ways of describing the repositioning of cultural icons or ideologies. To me these processes of recontextualization can be positive. They can be strategies of resistance. For instance, years ago I wrote an essay called "Sly Civility," which recounted how Christian missionaries in colonial India grew more and more anxious when Indians who had learned English and the symbology of Christianity started using that language. The missionaries said, “Now we are completely lost. Don't appropriate our languagewe don't know whether these Indians are fucking with us or whether they believe what we're saying; we can't control them anymore."

I think we need a positive way of thinking about these activities, these strategies of putting different things together, where the notion of ownership is somehow questioned, and some new perspective opens up.

\section{AJAY KURIAN:}

Most cultural creation right now utilizes appropriation in all of these different senses. It's pretty much 100 percent. There is appropriation, there's translation all over the place.

\section{HOMI BHABHA:}

I agree.

\section{AJAY KURIAN:}

There's no getting away from it, but I suppose I might be focusing on the negative aspect precisely because the positive aspect is a given of contemporary cultural production in the global marketplace. The negative plays an important role in orienting possibility.
HOMI BHABHA:

But not in isolation. "Don't take my symbols, don't misrepresent them in your work": These injunctions can be voiced by anyone, across the political spectrum. Appropriation need not only be across gender or color lines. Within the same gender, there can be class appropriations, there can be appropriations for all kinds of other forms of leverage. That doesn't mean that one political deployment of these tactics is interchangeable with anothereach needs to be assessed on its own terms, and they're far more complicated than the term appropriation allows. We need to ask: Why you are doing this? Why are you choosing to make this citation or juxtaposition?

And I think that notion of making a choice-a political choice, an aesthetic choice, and an ethical choice-is something that has to be countenanced. It's important to get some sense of the ways in which we can use these intersective, intergraphic, intermediatic relations as, again, strategies of resistance that enable us to take something from the house of the master and put it in the place of the slave, and produce something different for both.

\section{AJAY KURIAN:}

The other interesting point you raise, Homi, is intentionality. It's almost as if it's assumed that whatever cultural practitioner is putting these symbols next to each other is aware of what they're doing. But in fact, most of the time, it seems like they're horrendously ignorant of what they're doing. Like Katy Perry or Taylor Swift-there are so many videos where you're just like, "How the fuck did this happen? Who saw this and thought this was a good idea?" They're part of a media machine that exists to generate revenue, but still, you'd think there would be at least nominal checks and balances, someone to say, "Maybe don't touch that."

\section{HOMI BHABHA:}

You're quite right-the question of intentionality is misrepresented if it is presented as a fully conscious act of translation, intersection, montage. We can never quite control these acts and their signification. They exceed intention.

For example, the market has multiple aims-circulation, consumption, reification, profit, competition, exploitation-but we must never forget how important the market is in creating 
intercultural power dynamics, how important it is in making certain objects appropriate and others inappropriate, certain objects visible and others invisible. The market has as much to do with that as the media does in its circulation of certain forms of representation, certain forms of life, action, performance.

\section{MICHELLE KUO:}

That's what's striking about Dara Birnbaum, or early Warhol for that matter, stealing from mass media and commercial television versus a pop musician just broadly taking from culture at large. But what's also striking is that the culture industry has the most intentionality possible, right? They have so many resources, so many people thinking extremely deliberately about what they're doing. And that's power.

\section{GREGG BORDOWITZ:}

Well, it's interesting to use a term like culture industry now, just as it is to use the term appropriation now. Because actually the contemporary art world generates so much capital that it is on a continuum with the culture industry. I don't think we can talk about any museum or collection without recognizing that the so-called art world, at a level of high capitalization, is coextensive with popular entertainment. For example, Björk gets a show at the Museum of Modern Art [in New York]. I'm not saying anything bad about Björk or MoMA, I'm just trying to make the point that one can no longer pretend that fine art is somehow outside of the culture industry.

We must distinguish between expropriation and appropriation. Expropriation means to take someone's property. In Marx's theory of surplus value, the value of the hard work of laborers is expropriated from them. Appropriation means to take something, like an image, from a source perhaps belonging to someone else, quoting it, reusing it, repurposing it in one's own artwork. Outside the art world, one of the bravest acts of appropriation was Brazil's decision to buy AIDS drugs patented in the US and Europe and reverse-engineer them to produce high-quality, generic versions that were distributed to people with HIV in Brazil. It saved an enormous amount of lives, and the WTO reversed a lawsuit by scores of Big Pharma companies. It was a great victory. How is this related to art? The WTO regulations on intellectual property include drug formulas as well as cultural productions like movies and software.
With respect to the question of intentionality, I wanted to add that a certain degree of chance or unconscious choice is inherent in our everyday navigation of the electronic and digital media we use. If you're just clicking through cable channels, or going from one YouTube page to another, what you're doing in many ways is participating in a kind of randomized collection of images. Just do a Google image search on any term and see what pops up. We all do it every day. Search engines have particularly prescriptive algorithms, and yet there are still chance occurrences, collisions, and juxtapositions.

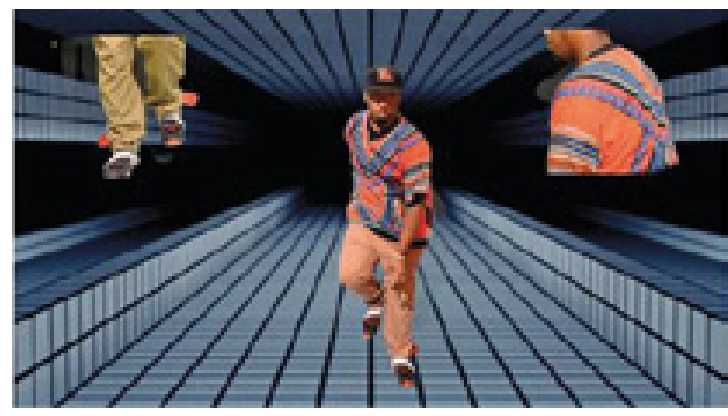

Figure 3. Salome Asega, Ali Rosa-Salas, and Chrybaby Cozie, Level Up: The Real Harlem Shake, 2015, interactive video game.

\section{MICHELLE KUO:}

This goes back to the question of the commons, which you brought up, Joan. Many of you are artists, maybe you view your work as the same as Katy Perry's, I don't know. But let's say there are different scales of production, even today, as it becomes ever more difficult to differentiate art from the so-called culture industry. What does that mean for the idea of a commons, in the sense of a common set of meanings and forms that are actually without ownership, in the capitalist sense?

\section{JOAN KEE:}

The scale issue is really important. The idea of the commonsespecially with respect to digital reproduction and technologygives rise to the fallacy that everyone has an equal share, or an equal role, in the production and reception of culture. And that is absolutely not true, of course, because some people have more access to resources than others.

And so it seems like the commons is really its own tragedy. You have demand for a given resource, but everyone who 
consumes that resource harms others who don't have the same access. So if part of the goal is to, say, flatten the scales of operation, then perhaps it's part of the duty for every individual to contribute to the development of the commons, rather than just endlessly taking from it.

\section{HOMI BHABHA:}

The commons can never be something that people simply consume. It has to be a productive, interlocutory relationship.

Now, it is an open question as to whether you can ever flatten out the commons. There can be equality of one kind, but there will always be inequality of another. This is what [W. E. B.] Du Bois meant when he said, "There can be color lines even within color lines."

Very often, though, equalization turns into universalization, and we have to be careful about that, because universalization is the enemy of historical specificity. It is the enemy of difference. The best we can do in defining a commonwealth is to create conditions where people can realize their agency, what Amartya Sen has called capabilities.

\section{GREGG BORDOWITZ:}

I've always thought of the commons as an ideal that exists in opposition to the market. The commons is a site of contestation; it's an attempt to hold on to some notion of the public-a liberal, bourgeois notion of the public that actually might have served us well, despite liberalism's contradictions.

I think the most radical thing that a work of art can do is to constitute a new audience, a group of people that never imagined themselves sitting in the same room. That is still the radical potential of art-this capacity to form what we used to call coalitions or alliances or affinities across boundaries of difference, to constitute new audiences, new constituencies, as opposed to appealing to a demographic. Constituencies have interests; demographics are groups of consumers. And constituencies can overlap, coexist-in other words, they allow us to conceptualize a public that isn't monolithic, where different groups can have different stakes in these incredibly fraught debates.Personally, I can't imagine coming up with one universal proposition that will lead us out of these tensions, because society is rife with the kinds of inequalities Joan and Homi mentioned. The answer is not going to emerge from any specific art-world controversy. It's so much larger than that.

\section{JACOLBY SATTERWHITE:}

I think these debates will phase out generationally. The new thirteen-year-old is ridiculously aloof from the issues we're talking about. The way culture is being disseminated, it's clear that we are the old farts contemplating something that is just going to fade away.

\section{MICHELLE KUO:}

I wondered if some of the controversies that have taken place in the art world in the past couple of years-is the generation of thirteen-year-olds mystified by all this?

\section{SALOME ASEGA:}

You think so?

\section{MICHELLE KUO:}

I don't know.

\section{SALOME ASEGA:}

I'm thinking about Amandla Stenberg.

\section{MICHELLE KUO:}

We don't even know who that is because we're too old! [Laughter.]

\section{SALOME ASEGA:}

Stenberg made a five-minute YouTube video defining cultural appropriation, called Don't Cash Crop on My Cornrows.

\section{JACOLBY SATTERWHITE:}

I feel like she was giving a 101 of what cultural appropriation means and why it's problematic, but as I said, in the near future it might be beside the point, because there will be a savviness in the way that people integrate ideas, just because they're born with or after YouTube. In the '90s, a white lady would dress up like a geisha in a pop video, and it was considered smart. That's not the environment today. 
For myself, I feel like, "OK, this is really controversial, I'm an angry political bitch." However, I choose my battles wisely because I'm an artist, and I have a specific type of vocabulary in the way that I work, and it's very sincere. But I think, for some people, calling out appropriation is about trends more than it is a sincere gesture. It's parodying. It's like "cornrows on a white girl," you know, and it's not smart. It's just: "Oh my God, I'm calling it out. I'm wearing a short skirt."

\section{SALOME ASEGA:}

I 100 percent hear that, but my question back to you then is, if young people have seen Stenberg's video, if they're learning to police in this way you're describing, what is the language they'll be using when they're older? Is this debate really going to phase out?

\section{JACOLBY SATTERWHITE:}

I don't think they'll be using that language. I think they're just parodying it. They'll read a couple of books, and they'll form their own arguments about what appropriation is. Right now, they're just parodying another generation's pain. And that video is just a viral video talking about stupid, frivolous shit that we shouldn't pay attention to. Those kids aren't paying attention-they're still looking at some dance in Bali somewhere, doing it in their bedroom.

\section{GREGG BORDOWITZ:}

How does one judge the sincerity of someone's pain? I followed the recent controversy over [Dana] Schutz's painting [Open Casket, 2016], though I couldn't come to any conclusion. I was confused. The debate revisited arguments l've witnessed before; the various positions formed a constellation of disagreements, each with historical precedents. The questions raised addressed unresolved and thus far seemingly intractable problems around race and representation, issues I've been thinking about for a long time.

One analogy that came to my mind was the movement to end the use of racist, stereotypical American Indian images for sports teams' logos. Perhaps this analogy is not completely appropriate to the situation at hand, but a long time ago, I heard an American Indian activist say, "What part of ouch do you not understand?" That really stuck with me. I mean, I could never presume to judge the sincerity of someone's claim to pain.

\section{JACOLBY SATTERWHITE:}

My generation feels more comfortable with that because we are the generation of the focus group, of YouTube comment boards.

\section{JOAN KEE:}

I don't think the expression of sincerity now is exactly like it was ten years ago, or ten years before that. There are certain frameworks within which certain texts or ideas are judged to be more sincere or more credible than others.

\section{MICHELLE KUO:}

What about the outrage surrounding the 2016 Kelley Walker show at the Contemporary Art Museum St. Louis, for example, which included well-known work that cites Warhol's Race Riots, among other imagery culled from historical and pop-cultural sources? That was obviously sincere, but there also seemed to be so many missed encounters and misunderstandings regarding the art itself, which, to my mind, remains a compelling examination of subjectivity and technology. What difference do media-photography versus painting, degrees of reproduction and transformation-and authorial identity make?

\section{JACOLBY SATTERWHITE:}

My view is: That series existed for a fucking decade and a half. That work circulated so hard, and no one had a problem with it. And that's what I meant when I said that when someone gets to a certain peak of power, that's when people suddenly notice their creative transgressions.

\section{AJAY KURIAN:}

No, I disagree. I don't think what happened was triggered by the artist achieving more power. The circumstances were so particular. To show that work in Saint Louis, in the wake of Ferguson, and then to have the institution 
be so ill-prepared to deal with the criticism, to have the artist be so ill-prepared to receive an audience that was voicing legitimate questions-it was bound to happen. The institution failed to provide a context, and the artist failed to be an active participant when asked to be. That is a perfect storm of complete tone-deafness.

\section{JACOLBY SATTERWHITE:}

Which isn't that surprising, because the discourse of image culture at the time those works were made is in some ways removed from the nitty-gritty of the politics of representation, the intersections of representation with identity, with the lived experience of racism, sexism today. . . .When those pieces were made, other concerns were at the forefrontthe ambivalence of the image, its circulation, monetization, digitization-and the concerns associated with the '90s art world fell by the wayside. And that was unfortunate-I don't agree with it. But I understand it contextually.

\section{HOMI BHABHA:}

This highlights another way in which the concept of translation is useful, I think: Appropriation and translation have different matrices of time, and different ways of addressing value and historical value.

Translation assumes that there will be interpretational changes over time relative to an anterior text, or work, or thing that came before. That's why I'm calling it anterior rather than original: There will be translations, there will be transformations. Time and displacement will contribute to these transformations. It's like having one of those in-built, slow-release tablets, where elements of the anterior object will emerge in different places at different times and constitute different things. So to think about the anterior-I know it sounds strange-is to emphasize the temporality of the event, object, or idea, its place in time rather than its exclusive possession of time as a frozen, immediate, or immovable moment.

Translation also assumes that the relationship of the anterior to the thing that follows can be tangential. It doesn't have to be mimetic or reflective. It's not a foundational relationship. It's a vectoral relationship, so that the translated object is not unrecognizable to the anterior object, but it has its own figurations, and configurations, and even deformations and misreadings. ... It's an interpretational intervention.

Then, if you accept translation, the problem is not one of continuity between the original and the belated; it is one of convergence. Things come from different places, through different media, different histories, and converge in a place, idea, or image. That convergence will itself become a moment of anteriority, out of which other translational and interpretational structures or figures will emerge.

Not for a second do I want to deny the historical specificity or cultural singularity of something that happens as if for the first time, or something that lives on in memory or history as a "primal scene," or some foundational event around which a history is built or destroyed. To recognize the "original" or the "authentic" as translational is decidedly not a form of pluralism or relativism without regard to agency or power or conflict. Translation as an activity of the anterior places an emphasis on what Walter Benjamin calls a "dialectical contrast": There is a space of resistance or displacement, revision and rearrangement, intervention and reinterpretation, reinvention and re-description, if you look for it hard enough and think about it long enough. At that point in time, the work of judgment and choice begins: What is a facile, self-aggrandizing, narcissistic appropriation? And what is a questing and questioning translation?

\section{GREGG BORDOWITZ:}

This goes back to what Ajay was saying about a lack of productive discourse: I think public discussion of these issues is extremely important. But I do not want to live in a world where this is legislated, where what can and cannot be done is prescribed by authority.

\section{AJAY KURIAN:}

No, it can't be legislated. But no one is telling Dana Schutz that she couldn't have made the painting.

\section{MICHELLE KUO:}

Well, some were saying that. 


\section{JACOLBY SATTERWHITE:}

People are saying it should be destroyed, which I don't like. An artwork should never be destroyed.

\section{GREGG BORDOWITZ:}

I don't want to see these things policed at the level of the law. In terms of feelings, pain, triggers, the kinds of contexts that we exist in now, I'm very, very sensitive to these concerns as an educator. I understand these from the perspective of someone who sees firsthand how teachers are responding to these challenges in the classroom. And I think discussion is the only way to meet the challenges, because context is very important. I think the Walker show in Saint Louis today is different than the work itself, regardless of Walker's propositions at the time of making it, or how he understood it. I think Glenn Ligon's essay on Walker [2010] was very instructive in that he read Walker's work as symptomatic of white culture's fascination with images of people of color. And that was an amazing and profound reading.

If you look at history-you know, patent laws are only around 150 years old or so-it wasn't until relatively recently that if you translated a book, you were considered the author of that book in the language of translation. So now we're at a historical moment where market regimes meet the commons and attempt to regulate it, with great success - but not total administration.

\section{JOAN KEE:}

One of the things that struck me about the controversy over [Schutz's] Open Casket is the certainty with which people clung to their opinions, to the point where there was absolutely no doubt. If you hated the painting, you hated the painting, and there was no talking beyond that. I see this in terms of the classroom too. This year, for the first time, all of my students were born after 2000. And it was striking to see the extent to which all of them just refused to discuss the controversy, because to them the call for discussion often seemed to be little more than the rehearsal of a limited set of truth claims. In terms of the discussion that does take place, is it really undertaken to reach consensus or resolution, or is it discussion for the sake of discussion?

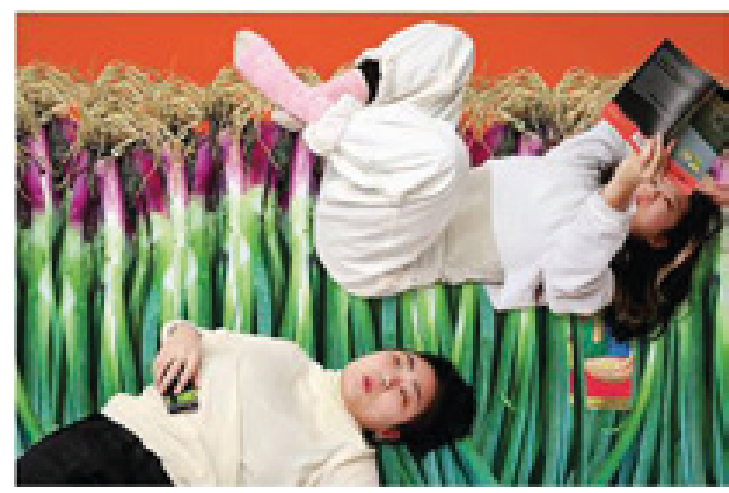

Figure 4. Yellow Jackets Collective, YJC, 2017, digital collage with photographs by Grace $\mathrm{Na}$ and Christal Sih.

\section{SALOME ASEGA:}

And how are we using or instrumentalizing images in those discussions? We've had Google now for twenty-plus years. We're used to the speed with which images come at us. And they seem to have a shorter life-span, too-we discuss them and then they go away. Are we slowing down and reading images? Or are we quick to talk about them, discard them, and let them die?

\section{JACOLBY SATTERWHITE:}

You don't really know if they're dead, though, because even if it's meme culture, memes sometimes get resurrected. We store these things, and they get repurposed. To be honest, I don't know if we are discarding them. I think our hard drives are really full, and it's probably changing the way the general culture engages with images.

\section{JOAN KEE:}

I agree. A lot of my students look at images as: "Let me accumulate this larger archive, and let me find an algorithm that can be endlessly replicated using all of these images that I've accumulated." Even as their attention spans are shorter, the database they are drawing from is much larger. And so for them it's about endless recombination and the alteration of images, as opposed to the intentional use of intact images so central to the legacy of Pop and the strategy of appropriation.

Their thinking is in turn transnational and transcultural, inflected by multiple and sometimes competing approaches to copying and borrowing. An example would be the attitude 
many of my students from China have regarding shanzhai, a word once used primarily to refer to criminal acts of copyright infringement. Now it's more frequently used to indicate open-source production aimed at expanding accessibility. But the ease with which physical appropriation is now possible is definitely part of the problem; for some, it justifies the flattening of art into a general stream of commerce, or, more problematically, for others, it suggests that using images without reference to context has ceased to be a legitimate issue at all.

\section{GREGG BORDOWITZ:}

But there are different art markets and even art worlds now, right? So I don't know if these positions or approaches can only be broken down into generational categories. For example, in the mainstream art world, there is still a premium placed on the handcrafted object, which has a certain market. (I'm not criticizing any particular method of artmaking, I'm talking about the operations of the market.) The old Marxist notion of unequal development is useful now, because it reminds us that we can't presume equal or homogeneous development everywhere. There is a huge portion of the world that does not have any access to the internet, or to the technology we're talking about. And incidentally, the global distribution of people without internet access doesn't necessarily map so easily onto "developed" or "developing" nations.

\section{HOMI BHABHA:}

Nothing is going to stop you from combining anything you want, just like nothing is going to stop you from plagiarizinguntil you get caught. You can appropriate what you want, but it's only when you get caught that the issue rises. And so the process itself, however technologically enhanced and generationally accepted it is, needs to have certain conditions of acceptance or criteria of judgment.

These criteria cannot simply be based on the taboo of appropriation, or the policing of what can or cannot be appropriated, because these forms of appropriation and translation will continue to be produced whether we like it or not, are in some ways inherent to our technological existence.

And so the point really, now, is not simply about the conditions of production. The question is: What are the conditions of reception? What are the "interpretational good practices," if I may coin a phrase? These practices could deal with meaning, with morality, with political implications-but they must be grounded in the belief of the importance of convergence rather than consensus, of acknowledging difference and criteria of judgment.

Again, we need to ask: By putting these different citations or images together, what is the story they're telling, and is that story one that you feel is useful? Is it saying something new? Is it pastiche or purely decorative? If the montage really does what montage does, which is not only put two things next to one another, but produce a tertium quid, produce something else, which displaces each of those images or texts and can be accumulated in an ever-increasing archive through technology, the question then becomes: What are the criteria-interpretational, political—of judging these constellations? What are the ethical criteria of acceptance?

\section{AJAY KURIAN:}

I've been reading a book on migration by Thomas Nail [The Figure of the Migrant, 2015] and it feels appropriate to how we are talking about images. Rather than talking about appropriation, we can also talk about the migrating image, and the sociopolitical dynamics that influence its movements. Since migration isn't neutral, Nail speaks in terms of the nomad, the barbarian, the vagabond, and the proletariat, addressing, among other things, the state of illegality-not "illegals" but the condition that so many people exist in today, that of illegality or statelessness. And that's a power relationship that is very distinctive.

\section{MICHELLE KUO:}

Hito Steyerl talks about the poor image, the low-res image that travels faster and farther now than ever before, in greater quantities than ever before, and that has a certain amount of power. The more low-res, the more impoverished it is, the faster it travels, and the more powerful it is because of its greater circulation.

But then it strikes me that some of the debates that have been coming up are precisely about arresting that circulation, or demanding that some images shouldn't be proliferating or 
circulating in that way. And so, that's another way to think about the movement of images, for better or for worse. Jacolby, Ajay, Gregg, Salome-all of your work and thinking does involve that in some way.

\section{SALOME ASEGA:}

And we have to think about the difference that arises when images circulate. My internet looks different from your internet, even if we're both using the same browser. Meanwhile, our machines are learning us, and are developing personalities that are like ours.

\section{JACOLBY SATTERWHITE:}

Doesn't it scare you when an app comes up while you're having a conversation on the phone, and it's from something you said out loud?

\section{SALOME ASEGA:}

Yes. Serious listening!

\section{JACOLBY SATTERWHITE:}

I've seen ads on Facebook that are aligned with my spoken conversation. Or if I search something on Instagram it can show up in my e-mail.

\section{MICHELLE KUO:}

Talk about appropriation. That is crazy.

\section{GREGG BORDOWITZ:}

I think this is the anxiety that underlies this conversation, this surveillance culture we live in, which works through appropriation, through the fact that the capacity for appropriation is built into the technologies we use every day.

And the intransigence of the positions within current debates is symptomatic of a much larger anxiety about living in a country that is deeply divided and run by a neofascist regime.

The president and his advisers model a certain kind of intransigence. What l'm afraid of is the politics of the litmus test, even if the objective is something I might support. For example, naming the names of museum board members who supported Trump during the election-where is that going to lead? It's a limited and dangerous strategy for the Left.

I remember in the LGBTQ movement, outing and shaming were poisonous to the atmosphere of queer activism, because they led to a litmus-test politics. And there's an old adage on the Left: "When the enemy is not in the room, we practice on each other." That is not a future I look forward to.

I'm really scared of that. l've seen it. I saw it in the movements I've been involved in, the AIDS activist movement and other left movements. I abandoned sectarian politics to join AIDS activism, because AIDS was never a single-issue political movement-the epidemic touched on every issue, and AIDS activism was nonsectarian, unlike the established Left of the late ' 70 s and early ' 80 s, which was hampered by terrible infighting. And now I feel that again, in the kind of politics that are arising now, and it's frightening to me.

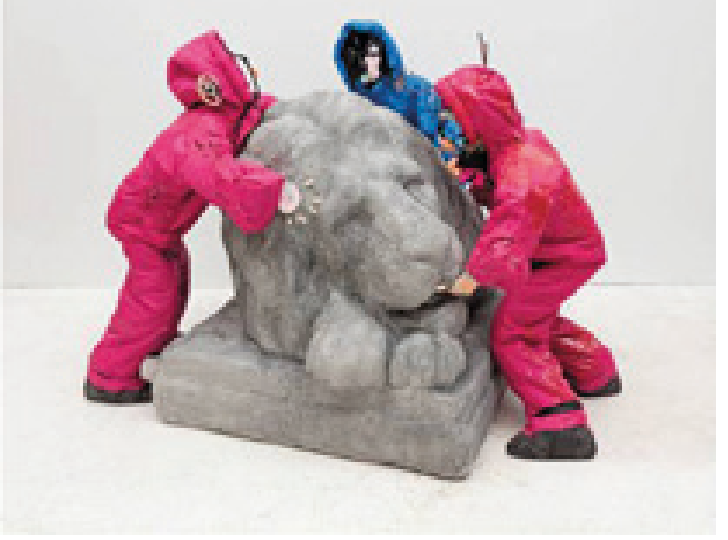

Figure 5. Ajay Kurian, Here to Help, 2016, wearable sleeping bags, aluminum wire, duct tape, epoxy clay, 3-D-printed cereal, plastic chain, fake leaves, sand, foam, concrete, Rockite, paint, hardware, incense sticks, polyurethane, $40 \times 66 \times 52$ ".

\section{HOMI BHABHA:}

What we understand as sectarianism is not so much that the enemy is out of the room as it is two other things: One, when the enemy is too complex to create a solidification or a solidarity among those who are contesting its power. Two when the enemy is itself internally complex, contradictoryyielding its power at one point, holding back at another. It's not that the enemy is outside the room, but that you cannot 
fathom who the enemy is when they are sitting inside the room, or the different faces of the enemy within the room.

Faced with that sort of complexity, oppositional groups tend to turn on each other, because of problems of strategy or of understanding. The trick is to make sure that you understand that there is a line beyond which you cannot go without collaborating with the powers you want to oppose.

\section{SALOME ASEGA:}

Postelection, l've been spending a lot of time thinking about what sort of accountability structures need to be put in place for when I fuck up, or for when people around me fuck up. And that doesn't necessarily mean shaming, but there needs to be at least some sort of code or set of rules in place.

\section{GREGG BORDOWITZ:}

I agree-there has to be a way that we can criticize each other and hold ourselves accountable. But l'm thinking about how to stage a critical discussion where we can encounter painful moments of difference and get through them.

\section{AJAY KURIAN:}

Now, on social media, when you put something out there, you're putting a period-as in, "end of discussion"-on the end of every single thing that you say. There was a moment where I would get involved in these Facebook fights, and every time l'd construct a comment it was intended as the final word; it wasn't dialogic. And I stopped doing it. I was like, This is ridiculous. I'm honing a toxic skill.

\section{JACOLBY SATTERWHITE:}

It teaches you how to type faster.

\section{AJAY KURIAN:}

And it teaches you how to throw up in your brain. It's a disgusting facility that people are getting really good at. It's not criticism, because there's no possibility of entering into dialogue with the other person. It's still the production of your self butting up against the production of someone else's self.

\section{MICHELLE KUO:}

And of course there are many people who have only seen Open Casket on Instagram or online; they've never seen it in the context of the show. Then there are many people who have seen the show and have no idea that this controversy is going on. So I think the ways in which an image, or a work, is ripped in isolation out of its context, which seems inevitable now, demands new forms of communication. If all that's left of discourse is a string of comments that are addressed to no one in particular, you can never have intersubjective meaningunderstanding another person, understanding meanings in a text or an image, understanding something outside of your own self. The only option left for art is autobiography. That's absurd, but how do you start to think about other models of conversation or exchange? You can obviously resist those structures, but are there other alternatives?

\section{JOAN KEE:}

One possibility might be to shift away from rights-based discussions and to instead consider what obligations we have and to whom they are owed. Of course this raises the question of who gets to administer these obligations, or, in short, of authority and enforcement. But at least it encourages thinking about participation as a recognition of debt rather than the exercise of entitlement. To wit, preliminary work has to be done at the register of attitude: humility rather than the presumption of omniscience. It might be that staging deliberate moments of failure is necessary.

\section{HOMI BHABHA:}

Put another way: How do we justly represent the views we contest or reject by doing the best we can to make sure that our opponents recognize that their views have been fairly represented and evaluated even when they are witheringly questioned or opposed? Coming from diverse histories, beliefs, and values, there has to be a vision that emphasizes the importance of convergence and that frees us to then go our own ways.

Convergence is process-driven, and "due process" in debate requires what l've called interpretational good practice. How does a community define this without subscribing to a notion of a free market of ideas, knowing that nothing comes for "free"? 


\section{GREGG BORDOWITZ:}

I think it has to start with recognizing that we are atomized to an unprecedented extent, and that we are all looking at multiple screens and taking in history in all kinds of different ways. And so the job of education is to establish a ground on which the student can conceptualize their subjectivity as a manifold self, using a constellation of histories, ideas, and convictions, references that may encompass art history but that will include other kinds of literacies and historical trajectories as well.

I agree with you, Jacolby, that appropriation will be framed very differently in the future, and it may be framed according to very different understandings of identity. New identity formations arise historically. For instance, "people with AIDS" is a relatively recent example of a new identity that traverses established boundaries to create new constituencies.

\section{AJAY KURIAN:}

Thinking about that atomization, it's funny, because in a sense the only thing that binds us together now is product. Everybody has an iPhone, everybody has some defining technology. "We have this" is our social intelligence now, a shared form of knowledge. For artists, it kind of makes sense to want to become Katy Perry or a megastar, because in order to become part of a shared social meaning, you have to turn yourself into product.

\section{GREGG BORDOWITZ:}

How do you create a context where you can have a roomful of people who are engaged in all these different practices and where the differences can be negotiated? It seems worthwhile to return to Aristotle's notion of poetics, as the discipline or practice shaping how you put things together. Composition becomes the common concept through which we can all talk to each other, across media. This may be a conservative pedagogical move, but perhaps it's a way toward establishing a common language for conversation.

\section{JACOLBY SATTERWHITE:}

I'm surprised Rachel Dolezal didn't come up today. [Laughter.]

\section{SALOME ASEGA:}

Stop.

\section{JACOLBY SATTERWHITE:}

I'm obsessed with her.

\section{AJAY KURIAN:}

Is it a kind of drag to you?

\section{JACOLBY SATTERWHITE:}

I like her black paintings. I love that she makes art.

\section{AJAY KURIAN:}

I had no idea.

\section{JACOLBY SATTERWHITE:}

She had a market. Those J. J. paintings from Good Times. Her paintings are like black-pride paintings you might see in a Korean hair store.

\section{GREGG BORDOWITZ:}

I understand why Dolezal was so disturbing. My identity politics, formed in the '80s, recognizes self-determination as the most important principle. Women's groups, people who occupy minority positions, especially oppressed positions, had and have the right to organize and to control spaces where they set the terms of discussion.

\section{MICHELLE KUO:}

But that kind of control is problematic.lt can, again, end up replicating the very structures of suppression that marginalize and repress.

\section{HOMI BHABHA:}

In all contexts of suffering, there is always the position of witnessing and there is the position of the testament. It seems to me that if you say, "Only those who have suffered, or who have been oppressed, can speak for the oppressed," it cuts out the possibility of building a larger coalition of people and structures that are opposed to forms of oppression and can speak for liberty or the common good. 
For instance, James Baldwin's critique of Elijah Muhammad [and the Nation of Islam] was, "We have enough problems creating one nation. Do we really want two?" Or his other great statement: "You cannot resolve the problem of African Americans without white Americans. You cannot resolve that issue, and you cannot displace it onto some Pan-Africanism either."

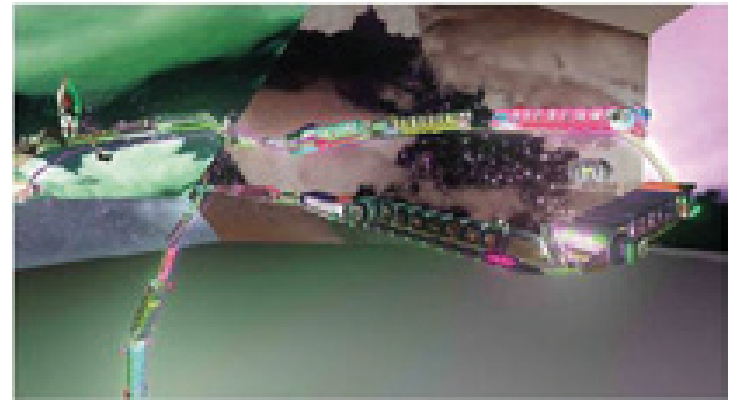

Figure 6. Jacolby Satterwhite, Pi, 2013, C-print, $30 \times 53 "$.

\section{MICHELLE KUO:}

$\mathrm{I}$ read the demand "only a person certified from $\mathrm{X}$ race is allowed to speak for that race" as a return to a fantasy of pure subjectivity; the end game is solipsism. How do you, on the one hand, further the dissemination of intersubjective thinking, of images, of ideas, regardless of where they come from or who thinks they own them—but on the other, how do you make sure that dissemination is done in a way that is, to use an anodyne term, productive rather than painful?

\section{GREGG BORDOWITZ:}

I guess I would say organizing. That's what I'm turning my attention to now. First, there must be a way for people of different identities to be allies for each other. I'm devoted to an ideal of coalition politics organized among activists for the purposes of sharing resources and supporting each other, putting our bodies on the line for each other when needed. I'm still looking for models like that.

I heard and took to heart what Stuart Hall told us in 1991 at the Studio Museum in Harlem - that we must go forward without the guarantees of essentialism. And now I don't know what happened to that moment.

\section{HOMI BHABHA:}

And so did we all; and we were right to do so. But we are in the midst of a ferocious erasure of the lives, experiences, and histories of the marginalized, the oppressed, of minorities. It's an old story but a new one, too. Undocumented migrants are immediately identified as criminals just because they cross a border-looking for work and absorbed into the informal economy-but suddenly they become fodder for fueling populist xenophobia and racism. When such erasures occur, there is an understandable desire to hold onto something that is your "own," that is not being taken from you or imposed on you for the power and profitability that is achieved at your cost. In such moments, people become possessive-unfortunately even "essentialist"-as if to stand up to hegemonic "fundamentalisms" with some alternative foundational identity or belief, with something that belongs to you that is endangered and vulnerable. And this raises the complex and contentious issue of appropriation.

This is a complimentary article. Subscribe to access the rest of the issue and our online archives. 